\title{
Vaart in de Innovatie van de Vervolgopleidingen (In VIVO): van terugkijken naar vooruitzien
}

Dit nummer van TMO is geheel gewijd aan het 'In VIVO'-project. Het project is eind 2006 gestart en duurt vier jaar. Het heeft als opdracht de implementatie van de nieuwe curricula van de specialistenopleidingen Kindergeneeskunde en Obstetrie \& Gynaecologie te faciliteren en te bestuderen. Deze twee specialismen zijn voorlopers in de operationele fase van de modernisering. Menigeen verwacht dat de modernisering van de specialistenopleidingen in Nederland met hindernissen zal verlopen. Het faseverschil in modernisering tussen Obstetrie \& Gynaecologie en Kindergeneeskunde als voorlopers en de andere specialistenopleidingen wordt gebruikt om alvast bruikbare praktijkervaring te vergaren. Die ervaring heeft betrekking op onderwijskundige aspecten, op succes- en faalfactoren uit het implementatieproces en op het voortschrijdend inzicht bij het stellen van overstijgende doelen en het maken van beleid op het terrein van zorg en zorgopleidingen. De effecten van 'In VIVO' kunnen dus liggen in het gebruik van de verzamelde ervaring door andere specialismen, maar ook in het gebruik door beleidsmakers die er beleidsaanpassingen op baseren. Dit themanummer geeft een eerste indruk van vergaarde ervaringen.

\section{De historie van de modernisering van de medische vervolgopleidingen}

\section{Motivatie maatschappelijk bepaald}

Het In VIVO-project was het gevolg van een aantal eerdere ontwikkelingen. Voor hen die op enige afstand staan van de op- leidingsvernieuwing in de specialistenopleidingen in Nederland worden deze ontwikkelingen hieronder in het kort beschreven. De maatschappelijke ontwikkelingen van de laatste tien jaar laten de gezondheidszorg niet onberoerd. In een periode waarin grenzen gesteld worden aan de financiële groei is vanuit de overheid transparantie en verantwoording van de beschikbare hoeveelheid geld die omgaat in de gezondheidszorg een steeds belangrijker punt van aandacht. Vooral aspecten van doelmatigheid en kostenbesparing, door bijvoorbeeld taakherschikking waarbij goedkopere professionals worden ingezet, worden in dit verband vaak genoemd. Daarnaast hebben beleidsmakers een visie op de specialist van de toekomst. Deze komt in een omgeving met verschillende, deels nieuwe soorten professionals te werken. Aan generieke competenties als samenwerking, leiderschap, organisatie en professioneel gedrag zullen hogere eisen gesteld worden. Tevens nemen consumenten van zorg een steeds kritischer houding aan, en niet altijd ten onrechte. Vrijwel iedere week kan de consument lezen over tekortkomingen in de zorg. ${ }^{1-2}$ Momenteel staat patiëntveiligheid in ziekenhuizen, waarvoor vooral het gebruik van bovengenoemde generieke competenties noodzakelijk is, sterk in de aandacht. ${ }^{3}$

\section{Wetgeving via het Centraal College Medische Specialismen}

Bovenstaande ontwikkelingen in de gezondheidszorg laten ook nationaal en internationaal het onderwijs in de specialistenopleidingen niet onberoerd. ${ }^{4-5}$ Ook hier 
zijn transparantie, verantwoording van middelen en kwaliteit belangrijke punten van aandacht. Bij kwaliteit gaat het om de kwaliteit van de opleidingen en die van de zorg. Om deze maatschappelijke invloeden te integreren in de opleiding tot specialist is ervoor gekozen het CanMEDS model als basis voor de specialistenopleiding te kiezen. ${ }^{6}$ Het CanMEDS model expliciteert de zeven verschillende algemene competenties waarover artsen zouden moeten beschikken (medisch handelen, communicatie, samenwerken, organisatie, maatschappelijk handelen, professionaliteit, kennis \& wetenschap). In het bijzonder de competenties anders dan medisch handelen, komen daardoor meer op de voorgrond te staan. Dit past bij de maatschappelijke ontwikkelingen, hoewel de implementatie ervan nog veel aandacht vraagt. ${ }^{7}$ De gemeenschappelijke colleges hebben het competentiegericht opleiden met behulp van het CanMEDS model verplicht gesteld in het kaderbesluit in 2004. ${ }^{8}$ $\mathrm{Na}$ goedkeuring van het ministerie van VWS is dit besluit per 1 januari 2005 wet geworden. De nadere uitwerking van het kaderbesluit werd gegeven door het CCMS (Centraal College Medische Specialismen): globale kaders waarbinnen opleidingen hun nieuwe opleidingsplannen moeten vormgeven. De kaders omvatten het competentiegericht maken van de opleiding, het gebruik van het portfolio, het toepassen van gestructureerde observaties (Korte Praktijk Beoordelingen KPB) gedurende de opleiding, het introduceren van de Critical Appraisal of a Topic (CAT) en de regelgeving over de aard en betekenis van voortgangs- en beoordelingsgesprekken.

\section{Plan van aanpak curriculumopbouw}

Het werd al snel duidelijk dat de wetenschappelijke verenigingen van verschillende specialismen zonder hulp niet in staat waren op korte termijn hun curricula te herzien. De noodzakelijke tijd en expertise ontbraken. Vandaar dat in september 2005 een begeleidingsgroep werd ingesteld (Begeleidingsgroep Beschrijving Opleidingsplannen Gezondheidszorg BBOV) welke tot taak had de wetenschappelijke verenigingen te coachen bij het schrijven van hun opleidingsplannen op basis van de criteria van het CCMS. Vanuit de BBOV werd een methodiek van curriculumbouw ontwikkeld die in de meeste curricula terug te vinden is..$^{9-10}$ De nieuwe opleidingsplannen in de medische vervolgopleidingen hebben vaak fraaie acroniemen als naam. Het recent opgeleverde plan van de chirurgen heet bijvoorbeeld SCHERP. Het eerste opgeleverde curriculum (2005), dat van Obstetrie \& Gynaecologie, heet HOOG (Herziening Opleiding Obstetrie en Gynaecologie). Het tweede curriculum, dat van Kindergeneeskunde (2006), heet GOED (Generieke Onderwijs en Evaluatie Doelen). Conceptcurricula worden na verwerking van feedback van de werkgroep Modernisering Medische Vervolgopleiding van het CCMS, definitief ter goedkeuring aan de plenaire vergadering van het CCMS voorgelegd. De implementatie van HOOG en GOED ging met de zegen van het CCMS van start al voordat het CCMS haar definitieve toetsingscriteria had ontwikkeld.

\section{Het 'In VIVO'-project voor Vaart in de Innovatie van de VervolgOpleidingen}

De beide voorlopers, Obstetrie \& Gynaecologie en Kindergeneeskunde, waren gemotiveerd voor een implementatiepilot van hun nieuwe curricula. Dit gegeven leidde tot het In VIVO-project. De subsidie voor het project werd verstrekt door het ministerie van VWS, thans via het CBOG (College voor de Beroepen en Opleidingen in de Gezondheidszorg). Resul- 
taten zijn producten, procedures en visies op 'best practices' met betrekking tot het competentiegericht opleiden en kwaliteitsborging, succes- en faalfactoren bij implementatie en een voortschrijdend inzicht betreffende het maatschappelijk verantwoord opleiden.

Dit themanummer over 'In VIVO' is geschreven op het moment dat het project halverwege de projectperiode zit. In termen van de veranderkundige Rogers ${ }^{11}$ sprekend is de adaptatie van de curricula grotendeels geslaagd. Het implementatieproces is in meer dan de helft van de centra in een ver gevorderd stadium. De komende jaren zal de implementatiegolf verder worden gestimuleerd, maar zal de focus gelegd worden op de kwaliteitsborging als onderdeel van de finale veranderfase: de institutionalisering, dat wil zeggen dat de innovatie is ingebed binnen de organisatiestructuur en ook onderhouden wordt. Het is een dynamisch proces. Al doende leren we en dienen doelen en de weg daartoe scherper in beeld te komen. Dat betekent dat geformuleerde doelen tijdens de implementatie kunnen verschuiven op geleide van de ervaringen; de zogeheten 'lerende interactie' overeenkomstig moderne implementatietheorieën. ${ }^{12}$ Een goed moment om stil te staan bij wat nu is bereikt en wat het perspectief is voor de toekomst.

De drie resultaatgebieden van In VIVO komen in dit themanummer via capita selecta aan bod.

\section{Onderwijskundige ontwikkeling}

- Bij de start van het In VIVO-project is gesteld dat het wenselijk is richtlijnen te formuleren voor het opleiden. Hierbij kan bijvoorbeeld gedacht worden aan het beoordelen van een portfolio, het beoordelen van vaardigheden op de operatiekamer en het afgeven van bekwaamheidsverklaringen. Het maken van richtlijnen past ook geheel in de gedachte van In VIVO dat deze producten ten goede kunnen komen aan andere verenigingen. Ten Cate et al. beschrijven het proces van het maken van een onderwijskundige richtlijn en de wijze waarop richtlijnen kunnen bijdragen aan de kwaliteit van het opleiden. In de loop van 2009 en 2010 zal het TMO deze richtlijnen als supplementen publiceren.

- Het inrichten van een toetssysteem vormt een belangrijk onderdeel van de implementatie. Van Luijk et al. beschrijven hoe de implementatie van de toetsinstrumenten in de diverse regio's heeft plaatsgevonden. Ook resultaten van een enquête onder artsen in opleiding tot specialist (aios) worden daarvoor gebruikt. Succes- en faalfactoren van de implementatie komen aan bod.

- Professionalisering van docenten en aios is een noodzakelijke voorwaarde om de implementatie van de opleidingsvernieuwing tot een succes te maken. Fluit et al. geven aan dat specifieke vaardigheden nodig zijn zowel voor de opleiders als voor de aios. Hiervoor staan verschillende modellen ter beschikking, variërend van groepsgewijze instructie tot individuele coaching. Dit artikel behandelt eveneens een aantal factoren voor een succesvolle professionalisering van aios en opleider. Baane et al. beschrijven hoe de professionalisering van aios zich op verschillende plekken in Nederland heeft ontwikkeld. Aios blijken enthousiast te reageren en dit type cursus vormt dan ook een belangrijke steunpilaar onder de modernisering. Deze lokale initiatieven zijn voorbeelden van wat er tot stand kan komen wanneer de modernisering ondersteund wordt door drie herhaaldelijk herkenbare succesfactoren: leiderschap, visie en 
een goede samenwerking tussen medici en onderwijskundigen.

\section{Implementatie}

- In het artikel van De Kroon et al. wordt ingegaan op een aantal factoren welke een rol spelen bij de landelijke implementatie van opleidingsplannen. Decentrale aansturing via zogenaamde 'kernteams' per regio zorgt ervoor dat binnen landelijke kaders de sturing van de vernieuwing dicht bij de werkvloer door de professionals zelf plaatsvindt. Het samen optrekken van verenigingen blijkt op hoofdlijnen zinvol en wenselijk, bijvoorbeeld voor wat betreft vorm en inhoud.

- Belangrijke parallelle ontwikkelingen aan de implementatie van de opleidingsvernieuwing kunnen een implementatieproces fors verstoren. ${ }^{13} \mathrm{Het}$ instellen van een opleidingsfonds is een dergelijke relevante ontwikkeling. Meningen verschillen echter over het effect. De Kroon geeft de kansen aan die een opleidingsfonds biedt voor het opleiden van aios. Brackel ziet als opleider echter ook bedreigingen voor de opleiding door het instellen van een opleidingsfonds op de huidige wijze.

\section{Voortschrijdend inzicht betreffende maatschappelijk verantwoord opleiden}

- Hoe de onderwijsvernieuwing beschouwd wordt als beleidsinstrument binnen de gezondheidszorg wordt toegelicht in het hoofdstuk van De Bont et al. Hier wordt duidelijk dat via overheden aangedragen doelen binnen de professionele discussie op de werkvloer evolueren tot een eigen agenda die vooral een kwaliteitsverbetering van de zorg nastreeft.

\section{Hoe gaat het project nu verder?}

Doorgaan op de ingeslagen weg met het implementeren van de instrumenten die verplicht gesteld zijn door het CCMS lijkt helder. Dat proces is nog niet afgerond. Ook een aantal richtlijnen dient nog verder ontwikkeld te worden. Kwaliteitsborging is een volgende fase. Daarnaast moeten we niet vergeten waarom de opleidingsvernieuwing is opgezet. Het gaat uiteindelijk om betere zorg voor de patiënt tegen beheersbare kosten. De komende jaren zullen we als professie zoveel mogelijk zicht moeten krijgen op de relatie tussen deze onderwijsvernieuwing en de uitkomst van zorg. ${ }^{14-15}$ Als we erin slagen verbanden te leggen tussen deze twee variabelen hebben we de beste gegevens om te blijven werken aan de verbetering van de kwaliteit van het opleiden en daarmee van de zorg voor de patiënt. En daar gaat het om!

\section{Fedde Scheele en Scheltus van Luijk}

\section{Literatuur}

1. Baltesen F. Slechte samenwerking ziekenhuizen al jaren bekend. NRC, 24 september 2008.

2. Schoenmaker E, Berg JMJ van den, Nugteren WAH. Nonchalance op de OK. Med Contact 2008;63:41.

3. De Bruijne MC, Zegers M, Hoonhout LHF, Wagner C. Onbedoelde Schade in Nederlandse Ziekenhuizen. Rapport van EMGO en NIVEL 2007; http://www.onderzoekpatientveiligheid.nl [bezocht op 8 oktober 2008].

4. Ludmerer KM, Johns MM. Reforming Graduate Medical Education. JAMA 2005;294:1083-87.

5. Bannon M. What's happening in postgraduate medical education? Arch Dis Child 2006;91:68-70.

6. Frank JR, Danoff D. The CanMEDS initiative: implementing an outcome based framework of physician competencies. Med Teach 2007;29:642-47.

7. Chou S, Cole G, McLaughlin K \& Lockyer J. CanMEDS evaluation in Canadian postgraduate training programmes: tools used and programme director satisfaction. Med Educ 2008:42:879-886.

8. Centraal College Medische Specialismen; Besluit van 9 februari 2004 houdende de algemene eisen voor de opleiding, registratie en herregistratie van medisch specialisten en voor de erkenning 
van opleiders, plaatsvervangend opleiders, stageopleiders en opleidingsinrichtingen; gepubliceerd in de Staatscourant van 14 december 2004, nr. 241.

9. Scheele F, Teunissen P, Van Luijk S, Heineman E, Fluit C, Mulder H, Meininger A, Wijnen-Meijer M, Glas G, Sluiter H, Hummel T. Introducing competency-based postgraduate medical education in the Netherlands. Med Teach 2008;30:248-53.

10. Ten Cate O, Scheele F. Competency-based postgraduate medical education: Can we bridge the gap between theory and clinical practice? Acad Med 2007;82:542-47.

11. Rogers EM. Innovativeness and adopter categories, chapter 7. In: Diffusion of Innovations, 5e editie, Free Press New York, 2003.
12. Grin J \& Staveren A van. Hoofdstuk 8, systeeminnovaties nader beschouwd. In: Werken aan systeeminnovaties. Van Gorcum, 2007.

13. Tijd voor Onderwijs; Eindrapport cie Parlementair Onderzoek Onderwijsvernieuwingen (vz Dijsselbloem), Tweede Kamer; juni 2008.

14. Mourad O \& Redelmeier D. Clinical Teaching and clinical outcomes: teaching capability and its association with patient outcomes. Med Educ 2006;40:637-644.

15. Haan CK, Edwards FH, Poole B, Godley M, Genuardi FJ \& Zenni EA. A model to begin to use clinical outcomes in medical education. Acad Med 2008;83(6):574-80. 